\title{
Microcredit - A More Credible Social than Economic Program in Bangladesh
}

\section{Rafiqul Islam Molla}

Specialist in Economics

Faculty of Business and Law

Multimedia University

Melaka, Malaysia

Email: rimolla@gmail.com

Md. Mahmudul Alam*

Postgraduate Student

Institute for Environment and Development (LESTARI)

Universiti Kebangsaan Malaysia

43600 UKM Bangi, Selangor Darul Ehsan, Malaysia

E-mail: rony000@gmail.com

*Corresponding Author

\section{Citation Reference:}

Molla, R.I., and Alam, M.M. 2011. Microcredit - A More Credible Social than Economic Program in Bangladesh, Economics Bulletin, Vol. 31(2), pp. 1095-1104. Available at <http://www.accessecon.com/Pubs/EB/2011/Volume31/EB-11-V31-I2P102.pdf >. (ISSN 1545-2921; Publisher- AccessEcon)

This is a pre-publication copy.

The published article is copyrighted by the publisher of the journal. 


\title{
Microcredit - A More Credible Social than Economic Program in Bangladesh
}

\begin{abstract}
Calculated under the framework of economic-profit counting, the productivity of microcredit in Bangladesh is found very low. In this survey about $48 \%$ of the borrowers had to compromise their normal wages for self-employed labor to be able to pay the high interest for the credit. Similarly its social productivity is also found marginal. However, about $90 \%$ of the borrowers felt comfortable with microcredit even at so high interest rate seemingly to avoid losing or compromising their social and political empowerment at the hands of the local moneylenders or relatives. Borrowers give high value to their socio-political empowerments and are ready to compromise normal wages for their self-employed labor. In the game of political economy of credit for the poor, microcredit is seen as a means of protecting and enhancing sociopolitical empowerments of the low income and distressed people in the society and is appraised as a credible social than economic institution.
\end{abstract}

Key Word: Grameen Bank, microcredit, microenterprise, subsistent, poverty alleviation, stereotype, empowerment

JEL Classification: C21, O12, O29

\section{INTRODUCTION}

Microcredit deals with very small scale financial service like savings and loans for productive as well as non-productive purposes like investment in productive activities, meeting emergencies, and day-to-day living, etc. Credit is usually provided without any collateral to groups of individuals or village organizations that bear joint-liability (peer pressure) to enforce loan repayment. Microcredit has launched a challenge to the formal financial system which denies any possibility of development to a large part of the world's population. By opening a window of opportunity for the low income people to take part and enjoy economic growth and human development microcredit has created a scope for reducing income inequalities and promoting poverty alleviation. Prof. M. Yunus, the founder of the Grameen Bank in Bangladesh, claims that microcredit program is an effective tool for enhancing income of the poor through creation of self-employed informal economic activities.

Bangladesh is called the land of microcredit with a high growth rate of microcredit borrowers. According to Palli Karma-Sahayak Foundation (PKSF 2006), it has 21.77 million total borrowers or 15.55 million effective borrowers after adjustment for multiple credit. Microcredit is delivered at an exorbitantly high interest rates ranging from 25-65\%. As a result the management and achievements of microcredit in the country have been highly 
criticized by many scholars, development practitioners, and politicians. The empirical studies by various scholars suggest that microcredit programs generated a positive change in the income of beneficiaries, but this change has been marginal with large number of the borrowers having no change in their economic and social status (Chavan and Ramakumar 2002, Ahmad 2007, and Molla et al. 2008). Remenyi (2000) observes that it will be too much to regard microcredit as a panacea for entrenched poverty in the developing world. The current finance minister of Bangladesh observed that even though microcredit could not possibly pull people out of poverty but it gave them a way for living (Star Business Report, 2009). Thus, the role of microcredit in reducing poverty and improving socioeconomic wellbeing of the poor in Bangladesh is very controversial with contradictory results of different researches. This paper aims to find if microcredit is more credible and productive as a social or economic institution.

\section{METHODOLOGY OF THE STUDY}

It is a descriptive research through a survey of current microcredit borrowers in Bangladesh. In the absence of full knowledge on the structure and distribution of the population of microcredit borrowers in the country, random sampling as representative sampling is neither possible nor desirable. Moreover, in many situations random sampling is not effective, or cost effective, for serving the purpose for which sample data are collected. Purposive or judgment sampling is effectively used in such cases. Accordingly, a judgment sampling procedure was thought more effective and appropriate for this survey. Data were collected from a sample of 555 current microcredit borrowers all over the country during January-April, 2008. Samples were selected from urban $(32 \%)$, semi-urban $(27 \%)$, and rural $(40 \%)$ areas by judgment to ensure that microborrowers of different sizes engaged in various categories of economic operations in rural and urban settings are adequately represented for analysis.

Data have been analyzed basically under a descriptive model using tabular analyses with the help of simple statistical tools like averages, percentages, ratios, etc. for a surgical analysis of the socioeconomic productivity of microcredit in terms of income generation, job creation, social empowerment, and total wellbeing of the borrowers to identify and evaluate its economic, social, and political role in their life management. However, it has been supplemented by an econometric analysis of economic productivity of microcredit using a Cobb-Douglas type production function. Since in some cases Y (net-worth) has negative values, it is not possible to use the log form. Therefore the following linear production model has been used:

$$
\mathrm{Y}_{\mathrm{i}}=\Omega_{\mathrm{i}}+\alpha_{\mathrm{i}} \mathrm{K}_{\mathrm{i}}+\beta_{\mathrm{i}} \mathrm{L}_{\mathrm{i}}+\varepsilon_{\mathrm{i}}
$$

Where, $\mathrm{Y}=$ Year end net-worth (in Tk) before paying family labor and interest cost

$\mathrm{K}=$ Full year equivalent capital/ investment (Tk)

$\mathrm{L}=$ Total labor hours

$$
\begin{aligned}
& \text { A, } \Omega=\text { Constant } \\
& \alpha, \beta=\text { Coefficient } \\
& \varepsilon=\text { Error term }
\end{aligned}
$$

For computation of elasticity, the following formula has been used: 
$\Psi=\zeta *($ Л / $\delta)$

Where, $\Psi=$ Elasticity value

$\zeta=$ Coefficient of respective variable $-\alpha_{\mathrm{i}}$ or $\beta_{\mathrm{i}}$

Л $=$ Mean of respective independent variable $-K_{i}$ or $L$

$\delta=$ Mean of the dependent variable $-\mathrm{Y}_{\mathrm{i}}$

$\mathrm{i}=$ Respective variable

The raw data were processed and analyzed in the Working Paper \# 2/2010 (Molla, 2010) and the forthcoming book: Inside Story of Microcredit in Bangladesh - An Empirical Investigation on the Role and Productivity (Alam \& Molla, 2011). Researchers in previous studies avoided the use of economic-profit counting method, that takes into consideration also the implicit costs like cost of self-employed family labor, in measuring the productivity or surplus generated from use of the credit. Only the present researchers successfully used this method in their pilot study in 2006 (Molla et al., 2008). Accordingly in this study, therefore, economic-profit counting, instead of accounting-profit counting, method has been used. Application of this approach may be claimed as a net addition to the literature on research methodology in this field.

\section{FEATURES OF MICROCREDIT AND ITS BORROWERS}

Microcredit borrowers are small producers or petty traders or small shopkeepers like tailoring shop, vegetable stall or peddling, fruits stall or peddling, fish stall or peddling, carpenter shop, hair cutting saloon, etc. They use the credit fund for consumption purposes and as capital for their different economic operations. It is found that about $15 \%$ of the borrower used the fund entirely for consumption (non-productive) purposes; the remaining borrowers used the entire or part of the credit fund for productive purposes. About $64 \%$ of the borrowers had total investments (borrowed and own funds) up to Tk 20,000 or below. A list of features of selected findings of the survey has been provided in Table 1 for easy reference, analysis, and discussions.

Table I: Features of selected findings of the survey of microcredit borrowers in Bangladesh, 2008

\begin{tabular}{|c|c|}
\hline Important Features & Data and Findings \\
\hline Sample size & Total sample : 555 \\
\hline $\begin{array}{l}\text { Amount of current credit per } \\
\text { borrower }\end{array}$ & $\begin{array}{l}\text { Tk } 15,342(\mathrm{Tk} 5,000-20,000-\text { for } 82 \% \\
\text { borrowers; including multiple credits) } \\
\text { exchange rate : US } \$ 1=\mathrm{Tk} 70\end{array}$ \\
\hline $\begin{array}{l}\text { Use of credit fund for } \\
\text { consumption }\end{array}$ & $15 \%$ of the borrowers \\
\hline Use of credit fund for investment & $\begin{array}{l}\text { Full amount- } 56 \% \text {; partial- } 29 \% \text {; with initial } \\
\text { additional fund }-28 \% \text {; topped-up fund } \\
\text { during the year }-21 \%\end{array}$ \\
\hline $\begin{array}{l}\text { Amount of full-year equivalent } \\
\text { current investment per borrower }\end{array}$ & Tk 16,424 (credit constitutes $81 \%$ ) \\
\hline $\begin{array}{l}\text { Amount of annual return on } \\
\text { investment per borrower }\end{array}$ & $\begin{array}{l}\text { Tk 33,654 after paying self-employed labor at } \\
\text { minimum wage rate - Tk8 for man; Tk } 5 \\
\text { for woman per hour } \\
\text { Tk. 9,341 after paying self-employed labor at } \\
3\end{array}$ \\
\hline
\end{tabular}




\begin{tabular}{|c|c|}
\hline & $\begin{array}{l}\text { market wage rate - Tk17.8 for man; } \\
\text { Tk12.4 for woman per hour }\end{array}$ \\
\hline Inability to pay any interest & $\begin{array}{l}7.6 \% \text { after paying self-employed labor at } \\
\text { minimum wage rate } \\
\text { 48\% after paying self-employed labor at } \\
\text { market wage rate }\end{array}$ \\
\hline $\begin{array}{l}\text { Ability to pay above } 60 \% \text { interest } \\
\text { with capital repayment }\end{array}$ & $\begin{array}{l}75.1 \% \text { after paying self-employed labor at } \\
\text { minimum wage rate } \\
33.8 \% \text { after paying self-employed labor at } \\
\text { market wage rate }\end{array}$ \\
\hline $\begin{array}{l}\text { Ability to pay more than } 25 \% \\
\text { interest with capital repayment }\end{array}$ & $\begin{array}{l}41 \% \text { after paying self-employed labor at } \\
\text { market wage rate }\end{array}$ \\
\hline Elasticity of Productivity & $\begin{array}{l}\text { Microcredit : } 44-46 \\
\text { Labor: } 46-49\end{array}$ \\
\hline Return to Scale & Decreasing for subsistent enterprise \\
\hline $\begin{array}{l}\text { Job creation (self-employment) } \\
\text { per Tk } 1000 \text { microcredit } \\
\text { investment for a year }\end{array}$ & 31.7 labor-days \\
\hline $\begin{array}{l}\text { Economic wellbeing of the } \\
\text { Households after using } \\
\text { microcredit - Improved }\end{array}$ & $86.50 \%$ borrowers reported \\
\hline $\begin{array}{l}\text { Use of microcredit by women } \\
\text { borrowers themselves }\end{array}$ & $10.6 \%$ of the women borrowers \\
\hline $\begin{array}{l}\text { Family level empowerment of } \\
\text { women borrowers }\end{array}$ & $\begin{array}{c}\text { Increased : } 37.48 \% \text { women borrowers; no } \\
\text { change } 34.8 \% \text { women borrowers }\end{array}$ \\
\hline
\end{tabular}

Source: Obtained from Table 1 of the Working Paper \# 2/2010 (Molla, 2010)

\section{ECONOMIC PRODUCTIVITY OF MICROCREDIT}

Interest rate for microcredit ranges from $25-65 \%$ while formal banking sector charges 10-12 percent interest for the small and cottage sector. The lenders argue that microcredit delivery and supervision cost is very high, and such a high interest rate charge is required to cover the high delivery costs. They also claim that the high rate of growth of the borrowers at this high interest rate indicates that the microcredit is highly productive and profitable for the borrowers, making them capable to easily pay this high interest. Unfortunately, when analyzing the benefits of the borrowers and effectiveness of the microcredit programs in developing countries, the lenders take resort to calculation of accounting profit of borrowers' business enterprises and ignore implicit costs under the plea that the opportunity cost of labor is near zero in these countries. This plea is certainly not tenable. It will, in fact, amount to going back to the concept of distressed selling of labor (much like slavery) of the medieval age and making microcredit a self defeating strategy for poverty alleviation (Molla and Alam, 2007). Therefore interest rate for microcredit should be consistent with its true productivity which should be measured taking into consideration all the implicit costs. This study, 
therefore, provides for opportunity costs for self-employed family labor in measuring the productivity of microcredit investments by the borrowers, under the framework of economic profit counting.

\subsection{Revenue and net worth of investment by economic approach}

Borrowers' average investment was Tk 16,424; and microcredit constituted $81 \%$ of full year equivalent investment. If we impute a minimum labor cost for borrowers' self employment, the rate of return on investment (ROI) is reduced from $430 \%$ to $254 \%$, and this rate declines to $28 \%$ if market rate of labor cost is applied for self-employment / family labor (Table 2). But behind this scenario of the average returns lies the truth of the deplorable situation. When minimum cost for family labor is charged the ROI for $7.6 \%$ of the borrowers become negative and when it is done at market wage rate the ROI for $47.6 \%$ of the borrowers become negative (Table 3). It therefore suggests that for about $48 \%$ of the borrowers microcredit investment is not productive to generate enough revenue for any interest payment if the market rates of wages is charged for self employment / family labor; but it is unproductive only for about $8 \%$ of them if minimum wage is charged for family labor. Therefore it appears that many (as many as 48\%) of the borrowers' self-employed labor (family labor) wages are compromised to find microcredit productive to command high interest payment. It is important to note that $48 \%$ borrowers who are deprived of the market rate of wages for their self employment remain vulnerable to default repayments. As a result $22.9 \%$ borrowers reported that they could not pay their repayment installments from the income of microcredit invested businesses.

\subsection{Econometric measurements of productivity}

Using the Cobb-Douglas type production function (Equation-1), the econometric analysis of the productivity of labor and microcredit also suggest that labor is relatively more productive than microcredit under both the assumptions that in subsistent enterprises a) male and female labors are equally productive, $b$ ) female labor is relative less productive to command a lower wage rate. A $1 \%$ increase in labor hour or labor cost increases the net-worth by $0.54 \%$ or $0.49 \%$, and $1 \%$ increase in microcredit investment increases the net-worth by $0.44 \%$ or $0.46 \%$ (Table 4). It is also found that the subsistent enterprises have reached the stage of decreasing return to scale supporting the fact that microcredit is primarily a program of poverty alleviation with very limited scope to be used for economic growth.

Table II: Return and Net Worth of Microcredit Investments

\begin{tabular}{llll}
\hline \multicolumn{1}{c}{$\begin{array}{c}\text { Net Worth and } \\
\text { Return on Investment }\end{array}$} & $\begin{array}{l}\text { Before } \\
\text { paying } \\
\text { Family labor } \\
\text { and interest }\end{array}$ & $\begin{array}{l}\text { After paying } \\
\text { family labor at } \\
\text { minimum wage } \\
\text { rate, but before } \\
\text { paying interest }\end{array}$ & $\begin{array}{l}\text { After paying } \\
\text { family labor at } \\
\text { market wage } \\
\text { rate, but before } \\
\text { paying interest }\end{array}$ \\
\hline $\begin{array}{l}\text { Average of borrowers' Net Worth or } \\
\begin{array}{l}\text { Surplus (Tk) } \\
\text { Average of borrowers' Investment (Tk) }\end{array}\end{array}$ & 52,282 & 33,654 & 9,341 \\
Average of borrowers' ROI (\%) & 16,424 & 16,424 & 16,424 \\
\hline
\end{tabular}

* Minimum labor cost per hour=man @ Tk 8, woman @ Tk $5 * *$ Standard labor cost per hour at market rate = man@ Tk 17.8,woman@ Tk 12.4

Source: Survey data

Table III: Borrowers by Interest Payment Capability from Business Returns (frequency) 
Interest Rate (\%)

Negative

Above 0 and up to 10

Above 10 and up to 25

Above 25 and up to 40

Above 40 and up to 60

Above 60

Total

* Considering minimum wage rate: male @ Tk 8, and female @ Tk 5 per hour.

$\wedge$ Considering standard/market wage rate: man @ Tk 17.8, and woman @ Tk 12.4 per hour.

** 1 person who was holding the credit fund at hand and the 81 non-investment cases are not included here

Source: Source: Survey data

Table IV: Productivity of Microcredit and Labor

\begin{tabular}{|c|c|c|c|c|c|c|c|}
\hline Measurement & Variable & $\begin{array}{c}\text { Coefficient } \\
(\alpha, \beta)\end{array}$ & Elasticity & $\begin{array}{l}\text { Return to } \\
\text { Scale }\end{array}$ & $\begin{array}{c}\mathrm{P} \\
\text { value }\end{array}$ & $\mathrm{R}^{2}$ & $\begin{array}{c}\text { Sample } \\
\text { Size }\end{array}$ \\
\hline \multirow{3}{*}{$\begin{array}{l}\text { Labor in } \\
\text { Hour }^{\text {a }}\end{array}$} & $\Omega$ & -1186.80 & & & 0.65 & & \multirow{6}{*}{$524^{\$}$} \\
\hline & K & $1.13 *$ & 0.44 & 0.98 & .000 & $0.53^{\wedge}$ & \\
\hline & $\mathrm{L}$ & $12.42 *$ & 0.54 & (decreasing) & .000 & & \\
\hline \multirow{3}{*}{$\begin{array}{c}\text { Labor in } \\
\text { value } \\
\text { (General) }^{b}\end{array}$} & $\Omega$ & 2146.01 & & & 0.41 & & \\
\hline & $\mathrm{K}$ & $1.18^{*}$ & 0.46 & 0.95 & .000 & $0.507^{\wedge}$ & \\
\hline & $\mathrm{L}$ & $0.57 *$ & 0.49 & (decreasing) & .000 & & \\
\hline
\end{tabular}

*Denotes significant at $1 \%$ significance level

${ }^{\wedge}$ In analyzing cross-sectional data R2 value of 0.53 or 0.51 is considered acceptable

$\$$ Includes 51 borrowers who have invested in multiple business activities $(473+51=524$ samples $)$

${ }^{a}$ Under the assumption there is no difference between male and female labor in terms of productivity

${ }^{\mathrm{b}}$ Labor hours weighted by market established standard wage rates for male and female reflecting the society's perception that female labor is relatively less productive to command a lower wage rate.

\subsection{Limited scopes for promoting microenterprises}

Initially, decades ago, microcredit was thought to be a growth generating tool in the pursuit of rural development. But now it is regarded basically as a tool for poverty alleviation. A stereotyped delivery system is designed and used for promoting and serving the survival and subsistence level economic activities, more particularly for poor female clients, through creation of self-employment opportunities according to their individual survival skills. Survey results suggest that to the extent that the activities are only at survival and subsistence level this standardized system is generally working. However, since the individual survival skills are different for different borrowers and they are pursuing different activities requiring credit supports differently, this stereotyped system may not be so effective for all the borrowers. This is particularly true for the microeconomic enterprises which are growth yielding small businesses like beyond subsistence level economic operations with a different nature of credit needs. Survey result shows that $11.7 \%$ of the microcredit borrowers were of this kind of potential or growing microentrepreneurs. It also shows that microcredit's standardised delivery system, particularly in respect of gender preference, loan size, loan disbursement and repayment schedules, was a strong limiting factor for effectively serving and promoting the microenterprises which required a more flexible credit package. It, therefore, suggests that a methodological modification is necessary to accommodate flexibility in microcredit delivery system. In the context of Bangladesh culture, male 
entrepreneurs are preferred more particularly in these business like microenterprises. As a result, for promoting this kind of enterprises, microcredit's attachment to and preference for female clients must be relaxed. The need for a separate credit package for microenterprises has been recognized by Grameen and other microcredit institutions in the country. As a matter of fact Grameen Fund (2010) has undertaken a separate project for providing loans to microenterprises, but under very restricted conditions which have made it, unfortunately, turned into almost a traditional commercial loan scheme. Most of the potential microenterprises are not able to enjoy the services and benefits of this loan program.

\section{SOCIAL PRODUCTIVITY OF MICROCREDIT}

\subsection{Job creation}

A fundamentally important claimed role of microcredit is job creation through promotion of self-employment. This study finds that for each Tk 1,000 microcredit invested for a year a 31.7-mandays of job was created (Table 5). In other words, for creation of a full-time annual self-employed job (310 labor-days of actual work in a year) it requires an investment of nearly Tk 10,000 microcredit fund. Though, in an earlier (pilot) study this was found to be Tk 12,000 (Molla, Alam and Wahid, 2008). It would be certainly interesting and desirable to study the job creation ability of other types of investments in the country. But we leave it for the future researcher to address it.

Table V: Job creation per Tk 1,000 microcredit investment for a year

\begin{tabular}{lcc}
\hline Types of Labor & Labor Hours & Labor Days** $^{* *}$ \\
\hline Average Job Creation for Man & 200.77 & 28.68 \\
Average Job Creation for Woman^ & 25.06 & 3.58 \\
\hline Total Job Creation* & 221.88 & 31.70 \\
\hline
\end{tabular}

$\wedge$ Woman spend time for receiving and submitting credit, that assume 50 hours annually, is not included here.

Only average job hours that women spent for the microcredit investment activates are consider here.

* Average of the jobs created by individual borrowers

** Full-time labor day is considered as 7 working hours per day

Source: Survey data

\subsection{Household economic wellbeing}

For Yunus (1993) microcredit program is an effective tool for enhancing income of the poor through promotion of various self-employed informal economic activities. The World Bank study on the impacts of the microcredit program of the Grameen Bank indicates that access to credit by the poor has increased self-employment. A BIDS study on rural poverty in Bangladesh showed that microcredit recipients had higher rate of growth in per capita income (Rahman et al. 1996). Similarly, in the present survey $87 \%$ borrowers reported that they had economic improvements after receiving the microcredit.

\subsection{Women empowerment}

Microcredit has been called "the" significant intervention in the fight against poverty for the twenty-first century (Rahman, 1998, p.80). The thrust of the movement has been especially to engage poor women, not only to alleviate poverty, but also to increase their access to resources and enhance their status and power in household decision-making (Sundram, 2001). But in reality women are found to be merely the media for obtaining the credit; in 
most cases their male family members actually decide and use the fund. It is found that in general only about $10.6 \%$ of the women borrowers used the credit by themselves (Table 6). In the remaining $89 \%$ cases actually the male members of their families decided and used the loan fund. Again, in terms of their empowerment at family level the picture was found unclear - about $39 \%$ claimed that their empowerment increased in the family, at the same time about $37 \%$ felt that their empowerment level in the family did not change (Table 7).

Table VI: Users of Credits Borrowed by Women Clients

\begin{tabular}{lc}
\hline \multicolumn{1}{c}{ Credit Fund Users } & Frequency \\
\hline Self & $57(10.6 \%)$ \\
Male Family Members & $453(84.4 \%)$ \\
Third Party & $11(2.0 \%)$ \\
No Response & $16(3.0 \%)$ \\
\hline Total & 537
\end{tabular}

* The male microcredit clients are excluded here - 18 cases out of 555

Source: Survey data

Table VII: Women Microcredit Borrowers' Assessment on their Social Empowerment

\begin{tabular}{lc}
\hline Assessment & Frequency of Borrowers \\
\hline Decrease & $5(0.95 \%)$ \\
Increased & $208(39.39 \%)$ \\
Same & $193(36.55 \%)$ \\
No Answer & $122(23.11 \%)$ \\
\hline
\end{tabular}

Total applicable women borrowers $528^{*}$

* Out of total 537 woman borrowers, 9 have no other members in the family and thus are not applicable for this analysis.

Source: Survey data

\section{MICROCREDIT AS A MORE CREDIBLE SOCIAL INSTITUTION}

It is interesting to note that about $57 \%$ of the borrowers did not believe that the interest rate for microcredit was unreasonably high; only about $36 \%$ believed otherwise (Table 8 ). We noted earlier that as many as $48 \%$ of these poor borrowers were willing to sacrifice and compromise their normal wages for their self-employed labor for the sake of socially and politically feeling better with microcredit compared to the informal credit from local moneylenders or relatives. Because in the first place interest charges by the moneylenders may not be less than that is charged by the microcredit providers. In addition, the poor borrowers generally lose a great deal of political and social empowerments in the hands of the moneylenders. As a result, even if the interest rate for microcredit is higher than moneylender's interest rate, micro borrowers prefer microcredit. In fact, they see microcredit as a savior of the social and political empowerments of the poor and the distressed in the society. It therefore lends support to the hypothesis that 'microcredit is more of a credible social than economic program'.

Table VIII: Borrowers' Views about Microcredit and its Interest Rate (frequency)

\begin{tabular}{|c|c|c|}
\hline \multirow{2}{*}{ Views } & & Microenterprise Subsistence \\
\hline & Borrowers & Borrowers \\
\hline
\end{tabular}




\begin{tabular}{llll}
\hline $\begin{array}{l}\text { Microcredit is good and not charging more } \\
\text { interest }\end{array}$ & $314(56.6 \%)$ & $38(58.5 \%)$ & $276(56.3 \%)$ \\
$\begin{array}{l}\text { Microcredit is good but charging more } \\
\text { interest }\end{array}$ & $186(33.5 \%)$ & $16(24.6 \%)$ & $170(34.7 \%)$ \\
$\begin{array}{l}\text { Microcredit is not good and charging more } \\
\text { interest }\end{array}$ & $13(2.3 \%)$ & $5(7.7 \%)$ & $8(1.6 \%)$ \\
No Comments & $42(7.6 \%)$ & $6(9.2 \%)$ & $36(7.3 \%)$ \\
\hline Total & 555 & 65 & 490 \\
\hline
\end{tabular}

Source: Survey data

\section{CONCLUSIONS}

Microcredit in Bangladesh is delivered typically through the non government organizations (NGOs) engaged in the promotion of economic and social development of the poor. Microcredit gained global recognition as a successful scheme for poverty alleviation. However, a surgical economic analysis reveals that its net economic benefit to the borrowers is at best marginal. About $48 \%$ of the borrowers had to sacrifice or compromise their normal wages for self-employed labor to be able to pay high interest for the credit. An econometric analysis of the productivity of labor and microcredit also suggest that labor is relatively more productive than microcredit. In terms of job creation similarly it is found to have a limited success. It requires investment of about Tk. 10,000 credit fund for a year for creation of one annual full-time self-employed job. Similarly it has a very little or no success in improving women borrowers' empowerment at the family level.

However, as many as $90 \%$ of the borrowers appreciated and felt comfortable with microcredit even at this high interest rate, ostensibly to avoid compromising their sociopolitical empowerments at the hands of the local moneylenders or relatives. In the game of political economy of credit for the poor, they see microcredit as a means of protecting and enhancing socio-political empowerments of the low income and distressed people in the society. It is thus appraised as a more credible social than economic institution.

\section{REFERENCES}

Ahmad, Q. K., Eds. (2007) Socio-Economic and Indebtedness-Related Impact of Microcredit in Bangladesh, UPL Publications: Dhaka.

Alam, M. M. and R. I. Molla (2011) Inside Story of Microcredit in Bangladesh - An Empirical Investigation on the Role and Productivity, VDM: Saarbrücken.

Chavan, Pallavi and R. Ramakumar (2002) "Micro-Credit and Rural Poverty: An Analysis of Empirical Evidence", Economic and Political Weekly 37(10), 955-965.

Molla, R. I. (2010) "Socioeconomic Productivity of Microcredit in Bangladesh: A Surgical Analysis", Working paper \# 2/2010, School on Local Development, University of Trento, Italy.

Molla, R. I. and M. M. Alam (2007) "A Reflection on Economics of Microcredit Borrowing in Rural Bangladesh", Journal of Business and Behavioral Science 18(1), 227-241.

Molla, R. I., M. M. Alam, and A. N. M. Wahid (2008) "Questioning Bangladesh's Microcredit", Challenge: The Magazine of Economic Affairs 51(6), 113- 121

Palli Karma-Sahayak Foundation (PKSF). (2006) Maps on Microcredit Coverage in Upazilas of Bangladesh, Dhaka, Bangladesh. 
Rahman, H. Z, and M. Hossain, and B. Sen (1996) Dynamics of Rural Poverty in Bangladesh, BIDS: Dhaka.

Rahman, R. (1998) "Micro-credit initiatives for equitable and sustainable development: who pays?", World Development 27(1), 67-82.

Remenyi, J. (2000) "Is there a 'State of the Art' in Microfinance", In J. Remenyi and B. Quinones, Eds., Microfinance and Poverty Alleviation Case Studies from Asia \& the Pacific, Pinter: London.

Star Business Report. (2009) "Microcredit failing to lift people out of poverty", Accessed August 12. Available at [http://www.bangladesh2day.com/newsfinance/2009/August/12/Micro credit-failing-to-lift-people-out-of-poverty.php]

Sundram, I. (2001) "Self help groups: Challenges and opportunities", Social Welfare 48(5), $18-19$.

Yunus, M (1993) "Alleviation of Poverty is a matter of Will, Not a Means", Acceptance Speech on the Occasion of Receiving the Care Humanitarian Hall in Washington D.C., USA. 